\title{
Perancangan Pemanfaatan Tenaga Surya untuk Penyaluran Air Bersih Bagi Pesantren Attuma'ninah Kab. Lebak, Banten
}

\author{
Adri Senen ${ }^{1}$; Tri Wahyu Oktaviana P. ${ }^{2}$; Dwi Anggaini ${ }^{3}$; Zainal Arifin ${ }^{4}$ \\ 1,2,3,4 Teknik Elektro, Institut Teknologi PLN \\ ${ }^{1}$ adrisenen@itpln.ac.id
}

\begin{abstract}
Clean water is one of the most vital human needs. Indonesia, which the largest part of its territory is water, in fact is still experiencing difficulties to meet the clean water needs of its population. Based on the data from the Central Statistics Agency in 2018, the percentage of households with clean drinking water sources is $72.99 \%$. Sajira Subdistrict in Lebak, Banten is one that is affected by severe drought. They always experience drought for 6-9 months annually. The people independently built water reservoirs from mountain water sources. Water is pumped using a water pumping machine and accommodated in reservoirs, then distributed to local residents through pipes with minimum distribution distance is $1 \mathrm{~km}$ from the reservoir. Due to long distance of the water distribution,many houses can't be reached by the water. It can be solved by adding a water pump in the reservoir. So the clean water distribution, which is initially only relies on pipes and gravity, can be maximized by the thrust of the water pump. Beside the water pump, the solar panel is also added to the system as a power supply. Thus, the residents don't need to pay for electricity bill to run the pumping system.
\end{abstract}

Keywords: Water distribution, Solar panel, clean water, water pump driven solar panel

\begin{abstract}
ABSTRAK
Air bersih merupakan salah satu kebutuhan manusia yang sangat vital. Negara Indonesia yang sebagian besar wilayahnya berupa perairan nyatanya masih mengalami kesulitan untuk memenuhi kebutuhan penduduknya dalam hal pemenuhan air bersih. Berdasarkan data dari Badan Pusat Statistik pada tahun 2018, persentase rumah tangga dengan sumber air minum bersih adalah 72,99 $\%$ (BPS, 2018). Kecamatan Sajira di Kabupaten Lebak merupakan kecamatan yang terdampak kekeringan dengan kondisi cukup parah. Kecamatan tersebut selalu mengalami kekeringan selama 6-9 bulan setiap tahunnya. Masyarakat Kecamatan Sajira secara swadaya membangun penampung air yang berasal dari sumber air gunung. Air dipompa menggunakan mesin pompa air dan ditampung di tandon untuk kemudian disalurkan ke warga sekitar melalui pipa dengan jarak penyaluran air minimal $1 \mathrm{~km}$ dari tandon. Akibat jarak penyaluran air yang jauh dari tandon, banyak warga yang mengeluhkan jika air tidak dapat sampai ke rumah mereka. Perbaikan dapat dilakukan dengan cara menambah mesin pompa air di tandon. Sehingga penyaluran air yang awalnya hanya mengandalkan pipa dan gaya gravitasi dapat dimaksimalkan dengan adanya daya dorong dari mesin pompa air tersebut. Selain itu ditambahkan pula sistem panel surya sebagai catu daya bagi mesin pompa air sehingga warga tidak dibebani dengan biaya listrik untuk pengoperasian pompa air.
\end{abstract}

Kata kunci: Penyaluran Air, Energi Surya, Air Bersih, Pompa Air Tenaga Surya 


\section{PENDAHULUAN}

Air bersih merupakan salah satu kebutuhan manusia yang sangat vital. Oleh karena itu ketersediaan air bersih menjadi hal yang harus selalu diperhatikan karena menyangkut kebutuhan primer manusia. Negara Indonesia yang sebagian besar wilayahnya berupa perairan nyatanya masih mengalami kesulitan untuk memenuhi kebutuhan penduduknya dalam hal pemenuhan air bersih. Berdasarkan data dari Badan Pusat Statistik pada tahun 2018, persentase rumah tangga dengan sumber air minum bersih adalah 72,99\% (BPS, 2018)

Salah satu provinsi yang selalu mengalami permasalahan krisis air bersih setiap tahunnya adalah Provinsi Banten. Dengan penduduk pada tahun 2018 sejumlah 12.689.736 jiwa (data BPS Prov. Banten), Provinsi Banten kesulitan untuk memenuhi kebutuhan akan air bersih bagi penduduknya. Seperti yang terjadi di Kabupaten Lebak tahun ini, kemarau panjang menyebabkan Kabupaten Lebak dilanda kekeringan terparah sejak 1997. Nazmudin, 2019). Dari 28 kecamatan di Kabupaten Lebak, 16 diantaranya mengalami kekeringan dan kondisinya memprihatinkan karena kesulitan akses air bersih.

Kecamatan Sajira di Kabupaten Lebak merupakan kecamatan yang terdampak kekeringan dengan kondisi cukup parah. Berdasarkan pengakuan warga, Kecamatan Sajira selalu mengalami kekeringan selama 6-9 bulan setiap tahunnya. Warga terpaksa memenuhi kebutuhan air dari sungai setempat yang kadang tidak layak konsumsi karena di sungai tersebut juga dijadikan warga sebagai tempat MCK (mandi, cuci, kakus). Alternatif air untuk konsumsi diperoleh warga dari sumber air yang letakknya cukup jauh dari pemukiman. Bahkan saat ini sungai tersebut sudah sangat kering akibat kemarau Panjang.

Masyarakat Desa Sukarame secara swadaya membuat sumur di dekat gunung agar terdapat sumber air bersih. Air dipompa menggunakan mesin pompa air dan ditampung di tandon untuk kemudian disalurkan ke warga sekitar melalui pipa dengan jarak penyaluran air minimal $1 \mathrm{~km}$. Akibat minimnya mesin yang tersedia, serta tidak adanya tandon yang layak, banyak warga yang mengeluhkan jika air tidak dapat sampai ke rumah mereka. Hal tersebut juga diakibatkan minimnya sumber listrik untuk mesin air dalam pemenuhan air bersih bagi warga Desa Sukarame. Selama musim kemarau, semua warga mengandalkan sumber air tersebut, hingga persediaan tidak dapat mencukupi kebutuhan warga. Oleh karena itu, sistem sumber air bersih perlu adanya perbaikan, agar kebutuhan warga akan air bersih dapat terpenuhi seluruhnya.

Perbaikan dapat dilakukan dengan cara menambah mesin pompa air dan tandon di Sumur tersebut. Sehingga tandon akan terisi lebih banyak air dalam waktu yang cukup singkat karna ada dua mesin air untuk memenuhi kebutuhan air bersih. Agar pengoperasian mesin pompa air tidak membebani warga dengan biaya listrik, maka ditambahkan pula sistem panel surya sebagai catu daya bagi mesin pompa air.

Permasalahan yang terjadi berkaitan dengan minimya air bersih khususnya bagi warga Desa Sukarame, Kec. Sajira Kab. Lebak dapat diatasi dengan adanya pengabdian kepada masyarakat yang dilakukan oleh civitas akademika IT-PLN sebagai salah satu bentuk Tri Darma Perguruan Tinggi. Berbekal pengetahuan mengenai tenaga surya maka dapat dipasang mesin pompa air di tandon swadaya masyarakat yang mengambil sumber melalui sel surya (solar cell). Penggunaan sel surya selain menguntungkan warga karena warga tidak perlu terbebani dengan biaya listrik, juga dapat menjadi sarana edukasi bagi masyarakat sekitar mengenai implementasi energi baru dan terbarukan. 


\section{METODOLOGI}

\subsection{Lokasi Kegiatan}

Program Kemitraan Masyarakat dengan tema "Perancangan Pemanfaatan Tenaga Surya Untuk Penyaluran Air Bersih Bagi Pesantren Attuma'ninah" yang berlokasi di Desa Sukarame, Kec. Sajira, Lebak Banten. Secara geografis Desa Sukarame berada pada -6,473268 lintang utara dan 106,361714 Bujur Timur. Luas wilayah sekitar $300 \mathrm{~m}^{2}$.

\subsection{Survey dan Analisa Ketersediaan Air Bersih}

Kecamatan Sajira di Kabupaten Lebak merupakan kecamatan yang terdampak kekeringan dengan kondisi cukup parah. Berdasarkan pengakuan warga, Kecamatan Sajira selalu mengalami kekeringan selama 6-9 bulan setiap tahunnya. Akibat minimnya mesin yang tersedia, serta tidak adanya tandon yang layak, banyak warga yang mengeluhkan jika air tidak dapat sampai ke rumah mereka. Hal tersebut juga diakibatkan minimnya sumber listrik untuk mesin air dalam pemenuhan air bersih bagi warga Desa Sukarame.

Kegiatan survey ini dalam pelaksanaanya melibatkan tokoh masyarakat setempat dan mahasiswa (gambar 1) sebagai anggota tim untuk membantu instalasi pemasangan panel dan instalasi penyaluran air bersih nantinya. Survey dilakukan sebanyak dua kali.

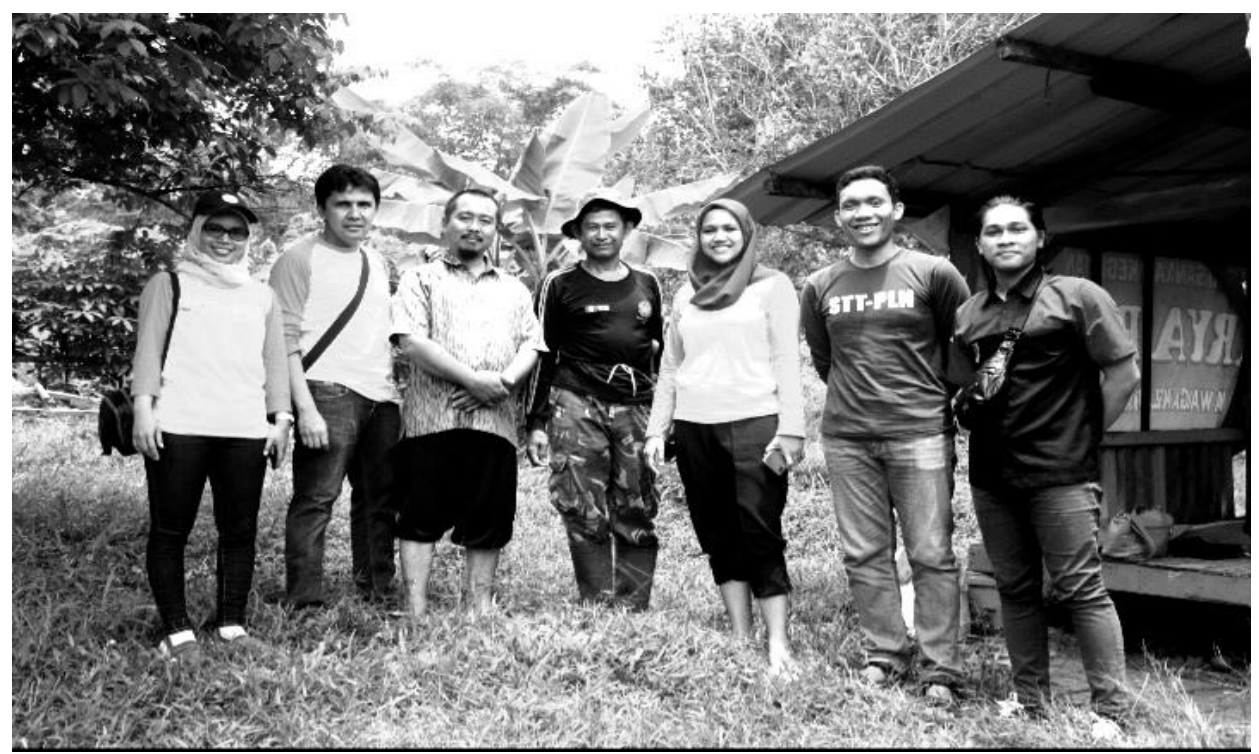

Gambar 1. Survey Lokasi

Survey dilakukan untuk menentukan dan mengukur debit air di lokasi tersebut, kontiniutas penyaluran air menjadi hal yang paling utama yang perlu diperhatikan, untuk memastikan itu maka dilakukan peninjauan dan pengukuran langsung ke sumber air yang ada serta dikuatkan dengan wawancara dengan warga setempat. Sumber air yang memungkinkan untuk disalurkan lokasi nya berada $1 \mathrm{~km}$ diatas pesantren yang akan disalurkan air bwersihnya.

\subsection{Sifat dan Bentuk Kegiatan}

Program Kemitraan Masyarakat dengan tema "Perancangan Pemanfaatan Tenaga Surya Untuk Penyaluran Air Bersih Bagi Pesantren Attuma'ninah di Desa Sukarame, Kab. Lebak, Banten dilaksanakan sekurang-kurangnya 2 kali survey ke lokasi yang dilakukan pada hari kerja yaitu dengan melihat lokasi sumber mata air dan jalur pendistribusian air yang memungkinkan untuk 
dipasang pipa dan pompa air listrik berbasis tenaga surya. Berdasarkan survei lapangan, dipilih tempat strategis yang bisa menjamin penyaluran air secara terus menerus dan hemat energi.Secara garis besar, metode pelaksanaan kegiatan pengabdian masyarakat ini adalah sebagai berikut:

Tahap 1: Tim mengadakan peninjauan lokasi ke Kecamatan Sajira Kab. Lebak, Banten untuk menentukan lokasi pemasangan pompa air Tenaga Surya.

Tahap 2: Tim menghitung dan menyiapkan beberapa peralatan diantaranya pompa air, panel surya, toran air dan pipa penyaluran air yang dibutuhkan

Tahap 3: Tim menyusun instalasi pompa air tenaga surya sesuai dengan lokasi yang telah ditentukan tim Bersama warga

Tahap 3: Tim Bersama warga memasang pompa air tenaga surya dan tandon air di Desa Sukarame, Kec. Sajira, Kab. Lebak Banten

Tahap 4: Tim memberikan sosialisasi tentang pengoperasian pompa air tenaga surya dan memberikan edukasi kepada warga tentang manfaat energi surya dalam teknologi dan kehidupan sehari-hari.

Tahap 5: Tim mengadakan evaluasi kegatan serta persiapan penyusunan laporan akhir kegiatan.

\subsection{Diagram Alir Kegiatan}

Metode yang digunakan dalam kegiatan ini adalah:

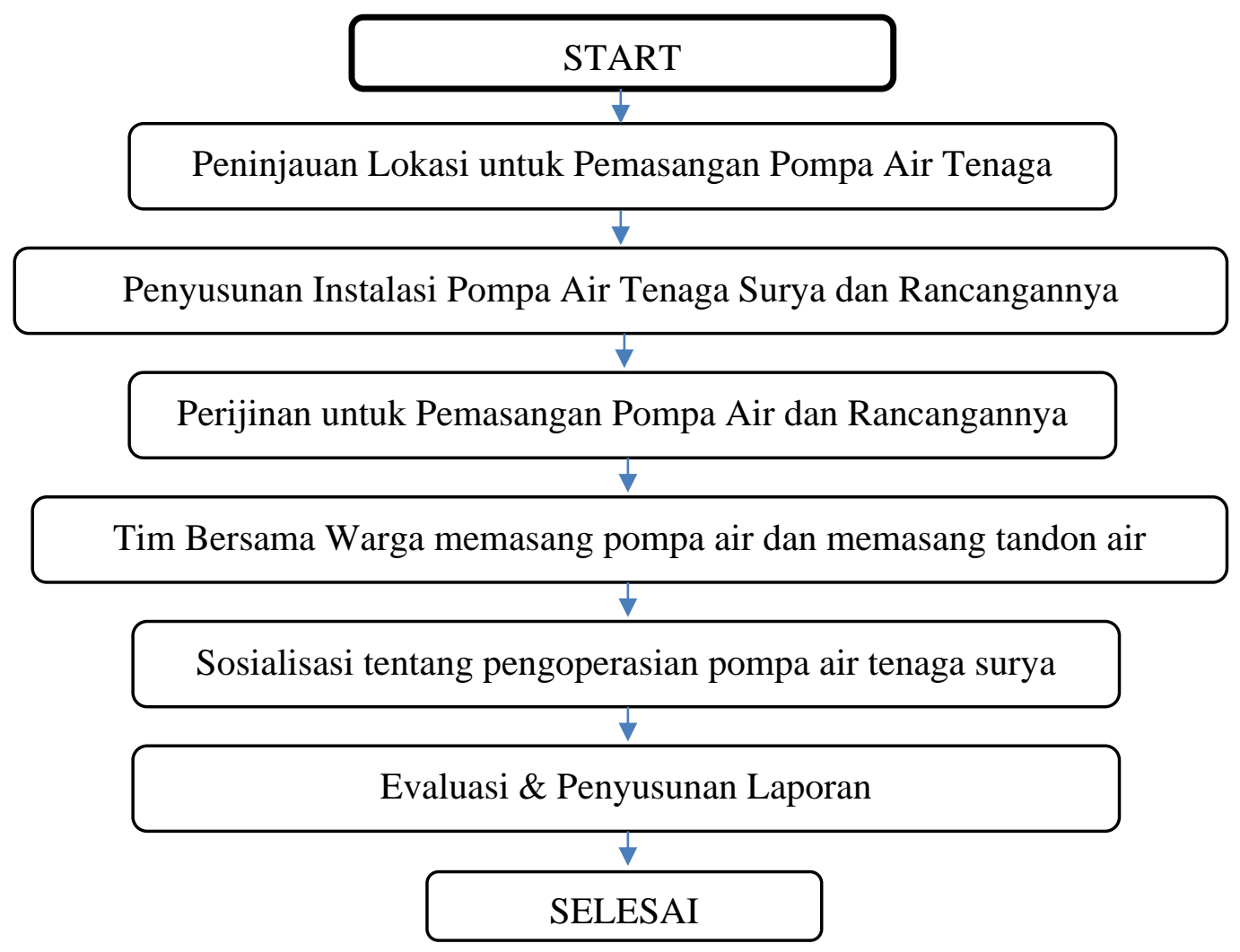

Gambar 2. Diagram Alir PKM 


\section{HASIL DAN PEMBAHASAN}

\subsection{Rancangan Sistem Pengambilan Air Bersih}

Sistem ini dimulai dengan merencanakan bangunan penampungan air bersih yang akan didistribusikan dari mata air yang terletak pada jarak sekitar $1 \mathrm{~km}$ dari pesantren. Adapun debit air berasal dari sumur yang berkedalaman 15 meter. Sumur berada dilokasi yang lebih tinggi dari pesantren dan tidak ada sumber energi listrik dari PLN, seperti yang terlihat pada gambar 3.a.

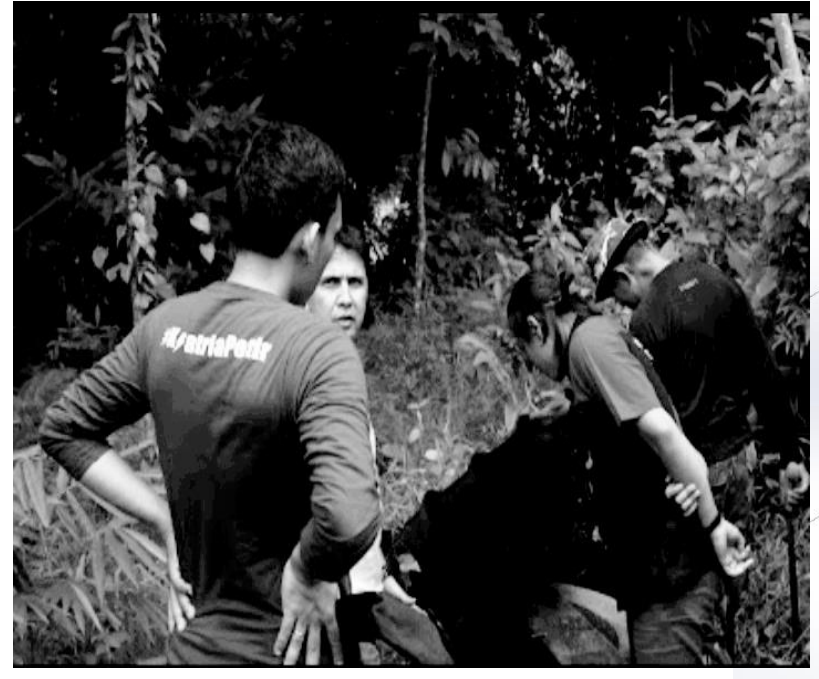

(a)

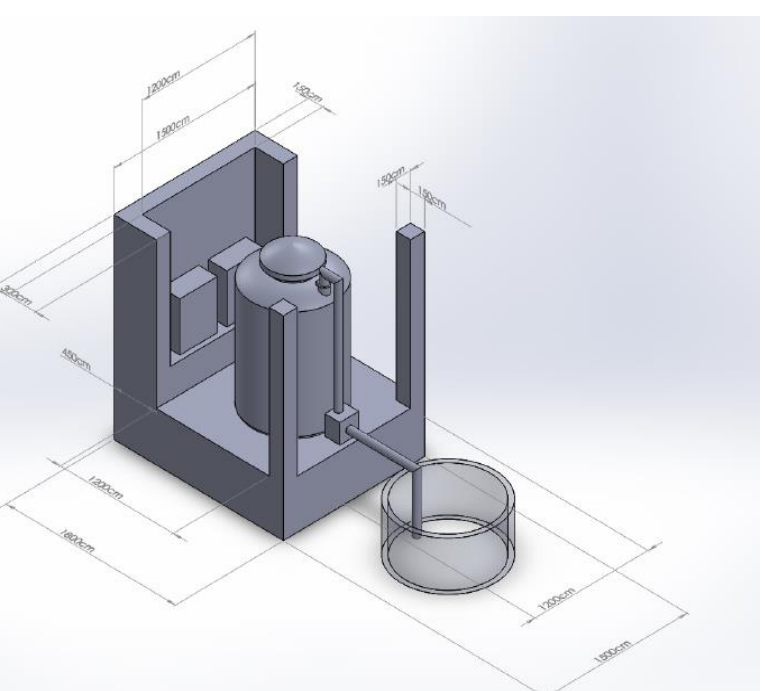

(b)

Gambar 3. Rancangan Pengambilan (Penyedotan) Air dari Sumber Mata air

Rancangan system pengambilan air nantinya akan didesain berdasarkan titik ssumber yang telah ditentukan. Gambara rancangan dapat dilihat pada gambar 3.b. Proses penyedotan dan penampungan air akan dibuat bak penampunag air yaitu menggunakan tandon berkapasitas $750 \mathrm{~L}$ (seperti terlihat pada gambar). Sedangkan untuk menarik air dari sumur menggunakan pompa air berkapasitasa 180 watt dengan sumber energi penggerak berasal dari panel surya yang berkapasitas $200 \mathrm{wp}$.

\subsection{Rancangan Sistem Penyaluran Air Bersih}

Air bersih yang telah dimasukkan ke toran menggunakan pompa air berbasis tenaga surya tersebut, selanjutya didistribusikan lagi ke tandon selanjutnya yang berjarak 50 meter dari tempat penampungan. Proses penyaluran air ke totan distribusi tersebut sama halnya dengan proses pengambilan air di sumur yakni dengan memasang lagi pompa air listrik tenaga surya. Adapun kapasitas toran airnya sama yaitu sebesar 750 L. Agar pompa air bisa berfungsi optimal maka dirancanglah tatatkan air seperti terlihat dari gambar berikut: 


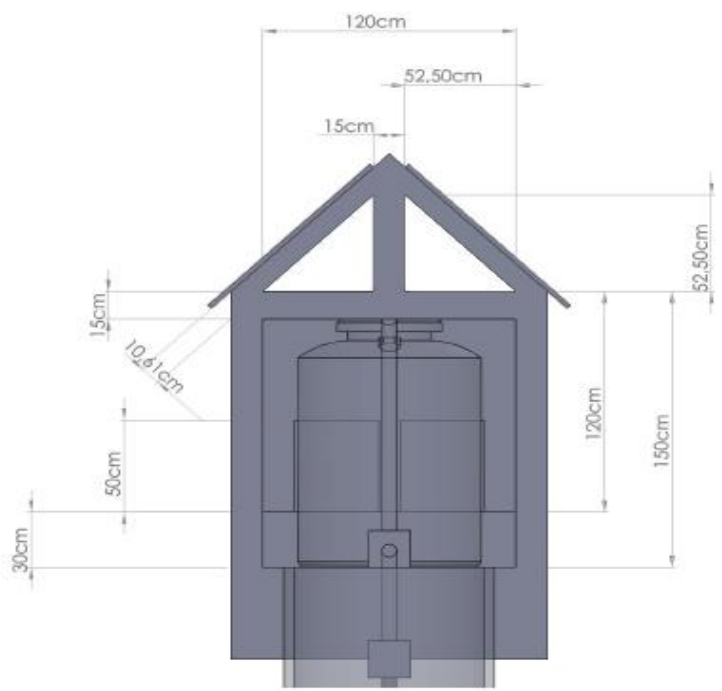

Gambar 4. Rancangan Posisi dan Tatakan Penyaluran Air Bersih

Setelah rancangan selesai digambarkan beserta ukurannya, selanjutnya hasil rancangan tersebut dikerjakan oleh tim beserta warga. Realisasi pengerjaan penampuang air dapat diihat pada gambar. Penampungan air ini terdiri keluaran distribusi nya akan dialirkan ke pesantren sekaligus disalurkan ke beberapa rumah warga disekitar, selain itu juga didistribusikan kepeternakan.
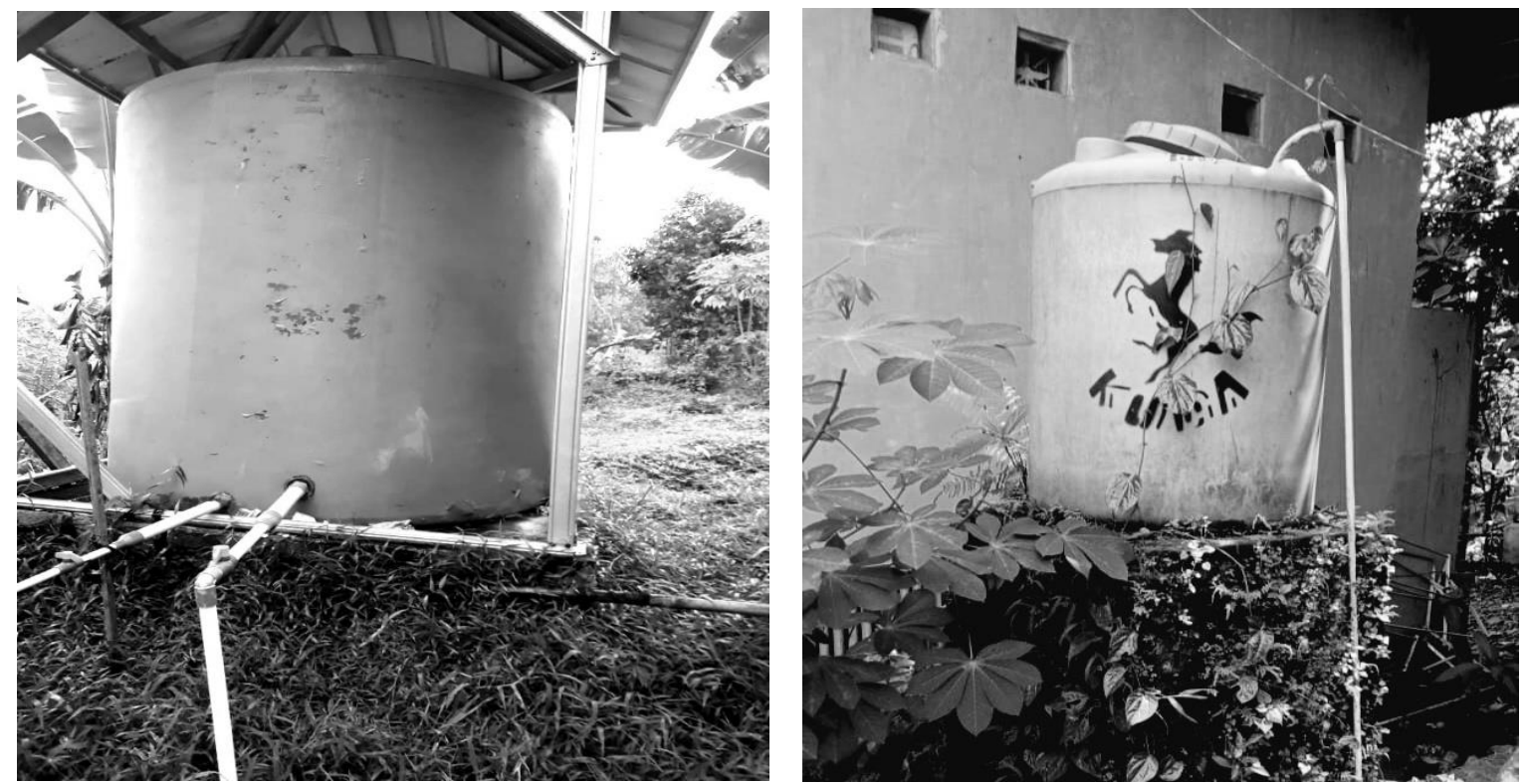

Gambar 5. Realisasi Penampungan Air untuk Penyaluran Air Bersih

Pengisian tandon air dilakukan sebanyak $3 \mathrm{x}$ dalam sehari. Mengingat kapasitas dan kemampuan pompa air tenaga surya hanya bisa beroperasi maksimal 4 jam dalam sehari. Untuk pengisian penuh tandon diperkirakan akan memakan waktu sekitar 1 jam.

\subsection{Rancangan Sistem Kontrol Pompa Air Ternaga Surya}

Perancangan sistem penyaluran air ini menggunakan solar panel sebagai sumber energi untuk men-supply daya pompa air. Sebelum dilakukan instalasi, maka terlebih dahulu dirancang dulu skematik dan tata letak peralatan agar dalam operasional dan pemasangannya bisa berjalan sesuai seperti apa yang diharapkan. Skematik instalalasi pemasangan dapat dilihat pada gambar 6 


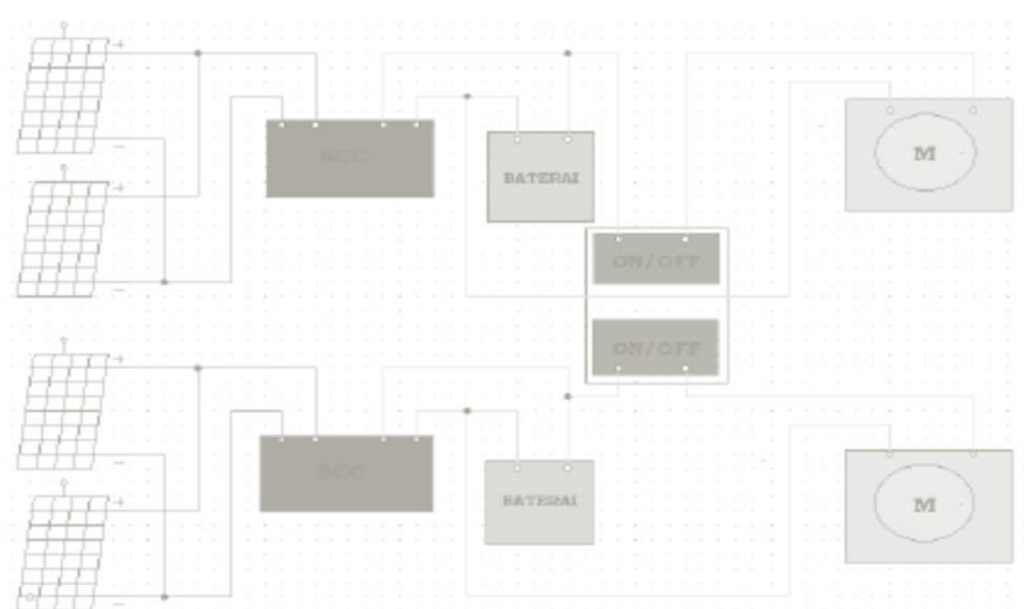

Gambar 6. Skematik Sistem Kontrol Pompa Air Listrik Tenaga Surya

Solar panel yang digunakan dalam kegiatan ini adalah solar panel jenis poly $100 \mathrm{Wp}$ sebanyak 2 unit, yang berdimensi masing - masing 1020 × 670 x $30 \mathrm{~mm}$ (seperti terlihat pada gambar 7). Selanjutnya Solar panel ini lah berfungsi mengkonversi energi cahaya matahari menjadi energi listrik. Energi yang dihasilkan oleh solar panel ini akan dihubungkan keperangkat Battery Charging Controller (BCC) melalui konektor ( solar change controller).

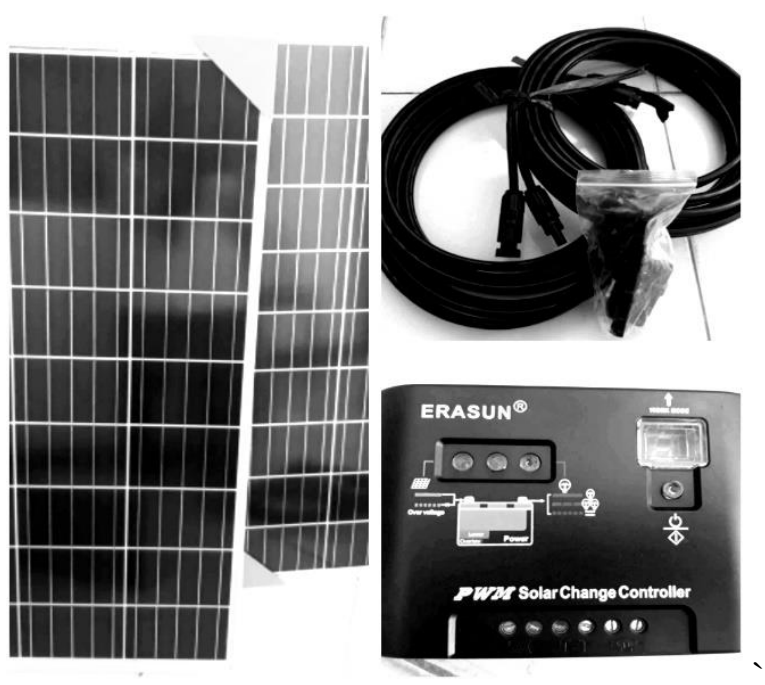

Gambar 7. Solar Panel dan Kontroller

Tipe battrai yang digunakan adalah Valve Regulated Lead - Acid Battery, VA 12 - 100 (berkapasitas $100 \mathrm{Ah} 12 \mathrm{~V}$ ) pada port input dengan polaritas (+) dan (-). Baterai dapat digunakan apabila panas radiasi matahari tidak bisa diserap oleh solar panel ataupun penggunaan daya yang dihasilkan oleh solar panel tidak mencukupi untuk mengoperasikan pompa air. Untuk sistem kontrol pompa akan dilengkapi dengan conector, kabel dan box panel outdoor. Semua peralatan ini dapat dilihat pada gambar 8 . 


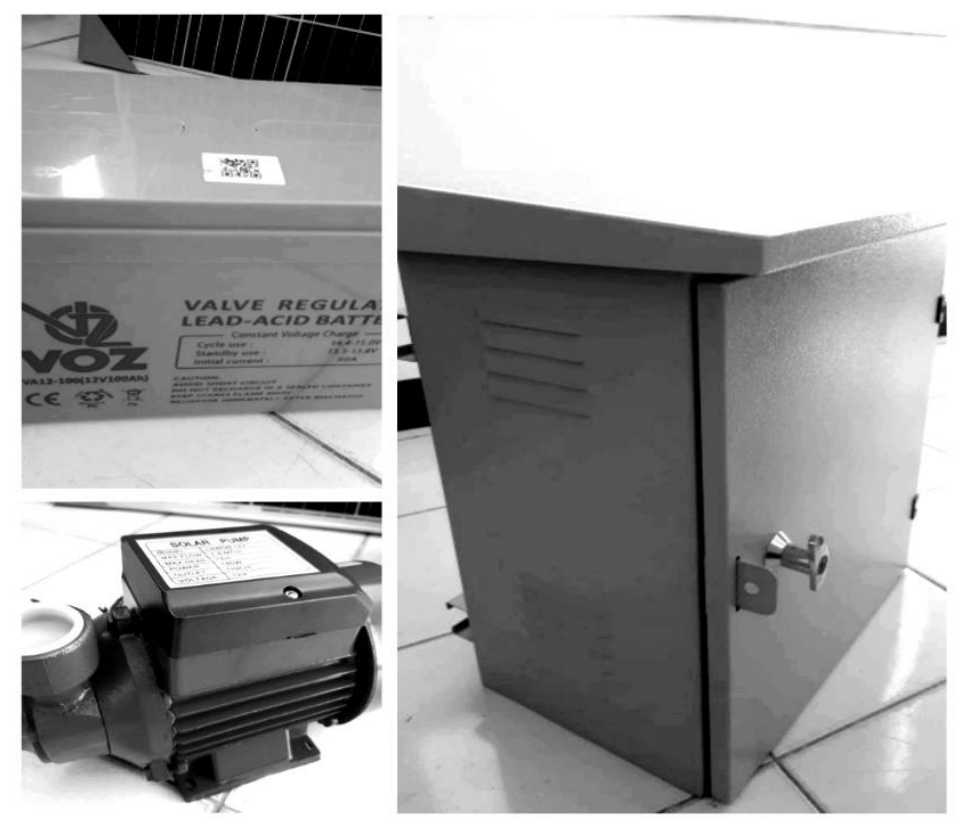

Gambar 8. Battry - Pompa Air - Panel Box

Untuk jenis pompa air yang digunakan adalah tipe Solar Pump dengan daya 180watt $12 \mathrm{~V}$, dengan kemampuan mendistribusikan air $1,5 \mathrm{~m}^{3} /$ jam dan daya sedot dengan kedalaman sekitar 15 meter. Semua peralatan tersebut nanti akan dipasang dalam panel box untuk keamanan dan estetika pemasangan agar lebih rapi dan memudahkan dalam instalasinya. Semua peralatan tersebut dapat dilihat pada gambar 8

\section{KESIMPULAN DAN SARAN}

\subsection{KESIMPULAN}

Berdasarkan rancangan dan kegiatan yang dilakukan maka dapat diperoleh kesimpulan sebagai berikut :

- Perancangan Pemanfaatan Tenaga Surya Untuk Penyaluran Air Bersih Bagi Pesantren Attuma'ninah Kab. Lebak, Banten mampu melayani kebutuhan akan air bersih secara kontiniu walaupun dimusin kemarau sekalipun dengan debit air sekitar 25 liter / menit

- Sumber air untuk penyaluran berasal dari sumur yang berada $1 \mathrm{~km}$ dari pesantren, untuk menyedot air tersebut digunakan juga pompa air bertenaga surya yang akan dikumpulkan pada bak penampungan (toren) yang berkapasitas $750 \mathrm{~L}$

- Air bersih didistribusikan ke pesantren juga memanfaatkan gravitasi memalui pipa distribusi karena sumber air berada diposisi lebih tinggi dari pesantren

\subsection{SARAN}

Rancangan Pemanfaatan Tenaga Surya Untuk Penyaluran Air Bersih Bagi Pesantren Attuma'ninah Kab. Lebak, Banten ini akan dapat berfungsi dengan maksimal jika sekiranya dalam pengoperasian dan pemeliharaan instalasi dilakukan dengan baik. Oleh karena itu perlu diperhatikan hal - hal sebagai berikut :

a. Memastikan sumber air tetap terjaga dengan baik

b. Perlu diadakannya manajemen dalam pengelolaan sistem penyediaan air bersih dan kepada pihak yang mengelola perlu diberikan pelatihan khusus terutama yang terkait dengan pemeliharaan pompa air dan panel surya nya. 


\section{UCAPAN TERIMA KASIH}

Penulis mengucapkan terima kasih kepada Institut Teknologi PLN Jakarta dan LPPM atas kesempatan kepada tim PKM dan dukungan baik moril maupun materiil serta pendanaan sehingga kegiatan PKM dapat terlaksana dengan baik.

\section{DAFTAR PUSTAKA}

[1] Anastasya Feby Makawimbang, Lambertus Tanudjaja, Eveline M. Wuisan "Perencanaan Sistem Penyediaan Air Bersih Di Desa Soyowan Kecamatan Ratatotok Kabupaten Minahasa Tenggara," Jurnal Sipil Statik Vol.5 No.1 Februari 2017 (31-40) ISSN: 2337-6732

[2] Fenny Nelwan, E. M. Wuisan, L. Tanudjaja "Perencanaan Jaringan Air Bersih Desa Kima Bajo Kecamatan Wori," Jurnal Sipil Statik Vol.1 No.10, September 2013 (678-684) ISSN: 2337-6732

[3] Alfredo Andrew, Tiny Mananoma, Jeffry S.F. Sumarauw, "Perencanaan Sistem Penyediaan Air Bersih Di Desa Rambunanan Amian Kecamatan Sonder Kabupaten Minahasa", Jurnal Sipil Statik Vol.6 No.12 Desember 2018 (1055-1064) ISSN: 2337-6732.

[4] Manan, Saiful. 2009. Energi Matahari, Sumber Energi Alternatif Yang Effisien, Handal dan Ramah Lingkungan di Indonesia. Gema Teknologi

[5] Jaelani, A., Energi Baru Terbarukan Di Indonesia: Isyarat Ilmiah Al-Qur'an Dan Implementasinya Dalam Ekonomi Islam. University Library of Munich, Jerman. 2017.

[6] Nazmudin, Acep, "Alami Kekeringan Terparah Sejak 1997, Ribuan Warga Lebak Gelar Shalat Minta Hujan". Diakses online https://regional.kompas.com/read/2019/08/22/11113141/alami-kekeringan-terparah-sejak1997-ribuan-warga-lebak-gelar-shalat-minta.2019

[7] BPS, "Statistik Kesejahteraan Rakyat 2018". Jakarta: Badan Pusat Statistik. 2018. 